\title{
Breeding Buckwheat for Increased Levels of Rutin, Quercetin and Other Bioactive Compounds with Potential Antiviral Effects
}

\author{
Zlata Luthar ${ }^{1}$, Mateja Germ ${ }^{1}$, Matevž Likar ${ }^{1}{ }^{\mathbb{D}}$, Aleksandra Golob ${ }^{1}$, Katarina Vogel-Mikuš ${ }^{1,2}$,

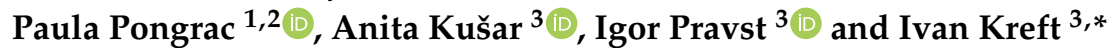 \\ 1 Biotechnical Faculty, University of Ljubljana, Jamnikarjeva 101, SI-1000 Ljubljana, Slovenia; \\ zlata.luthar@bf.uni-lj.si (Z.L.); mateja.germ@bf.uni-lj.si (M.G.); matevz.likar@bf.uni-lj.si (M.L.); \\ aleksandra.golob@bf.uni-lj.si (A.G.); katarina.vogelmikus@bf.uni-lj.si (K.V.-M.); \\ paula.pongrac@gmail.com (P.P.) \\ 2 Jožef Stefan Institute, Jamova 39, SI-1000 Ljubljana, Slovenia \\ 3 Nutrition Institute, Tržaška 40, SI-1000 Ljubljana, Slovenia; anita.kusar@nutris.org (A.K.); \\ igor.pravst@nutris.org (I.P.) \\ * Correspondence: ivan.kreft@guest.arnes.si; Tel.: +386-1-3007981
}

Received: 9 October 2020; Accepted: 23 November 2020; Published: 24 November 2020

\begin{abstract}
Common buckwheat (Fagopyrum esculentum Moench) and Tartary buckwheat (Fagopyrum tataricum (L.) Gaertn.) are sources of many bioactive compounds, such as rutin, quercetin, emodin, fagopyrin and other (poly)phenolics. In damaged or milled grain under wet conditions, most of the rutin in common and Tartary buckwheat is degraded to quercetin by rutin-degrading enzymes (e.g., rutinosidase). From Tartary buckwheat varieties with low rutinosidase activity it is possible to prepare foods with high levels of rutin, with the preserved initial levels in the grain. The quercetin from rutin degradation in Tartary buckwheat grain is responsible in part for inhibition of $\alpha$-glucosidase in the intestine, which helps to maintain normal glucose levels in the blood. Rutin and emodin have the potential for antiviral effects. Grain embryos are rich in rutin, so breeding buckwheat with the aim of producing larger embryos may be a promising strategy to increase the levels of rutin in common and Tartary buckwheat grain, and hence to improve its nutritional value.
\end{abstract}

Keywords: breeding; buckwheat; flavonoids; rutin; quercetin; emodin; fagopyrin; antiviral activity

\section{Introduction}

Common buckwheat (Fagopyrum esculentum Moench) and Tartary buckwheat (Fagopyrum tataricum (L.) Gaertn.) are traditionally grown in the Himalayas, south-western and northern China, Korea, Japan, and central and eastern Europe [1,2]. Two types of buckwheat are mainly used around the world: common buckwheat and Tartary buckwheat. Which buckwheat species is used depends on the production zone and the way of utilization. Generally, in Europe, the USA, Canada, Brazil, South Africa and Australia, the common buckwheat prevails. This holds true for most Asian buckwheat-growing countries, e.g., Japan, Korea, and the central and northern parts of China. Tartary buckwheat is grown and used in the mountain regions of Himalaya. In northern India, Bhutan and Nepal both types are known, yet Tartary buckwheat is grown in harsher climatic conditions. Tartary buckwheat flour is recently increasingly used in preparing dishes due to its even higher content of rutin in comparison to of common buckwheat.

Buckwheat is a low-input plant, suitable for growing in harsh ecological conditions, decreasing the density of invasive wireworms, with ecotypes showing preharvest sprouting resistance, shattering resistance, and lodging resistance $[3,4]$. Buckwheat is expected to be an even more important plant in 
agriculture and a dish in the cuisine and dietary habits in many countries, including those of Asia, Europe and America [5]. Besides the agricultural, cultural and culinary value of buckwheat, recently more emphasis has been placed on its health-related and nutritional value; well-balanced amino acid composition of proteins, dietary fiber, content of mineral elements and vitamins, as well as rich content of diverse antioxidants, mainly flavonoids rutin and quercetin [6,7]. Novel buckwheat dishes and products, including diverse pasta products, grain-based products, sprouts and young plants, have potential in Asia and in Europe.

Common buckwheat and Tartary buckwheat are used in different parts of the world to make various food products. One of reasons for buckwheat's popularity is the ability to repress weeds and the relative resistance of buckwheat to pests and diseases $[3,8]$. Buckwheat is thus suitable for biological (organic, ecological) cultivation. Buckwheat groats are a prebiotic food because they have increased amounts of resistant starch [9].

Buckwheat does not contain gluten proteins, so it is safe for people who require a gluten-free diet [10]. Buckwheat can increase food diversity, evokes tradition and in a way revives the heritage of "the good old days".

While common buckwheat breeding has been widespread in Japan, China, Korea, Poland, Ukraine, Belarus, Russia and Slovenia, new Tartary buckwheat varieties have been released only recently in China, Japan and Slovenia. Until now, the breeding of common and Tartary buckwheat has focused on achieving high yields and resistance to unfavourable environmental conditions. As these buckwheat species are both good sources of polyphenolic compounds, more attention is now being directed towards optimisation of their nutritional quality parameters, and increasing their content of flavonoids (e.g., rutin, quercetin) and other phenolics [11]. In this review, we will appraise recent attempts to develop common and Tartary buckwheat for grain with higher flavonoid and emodin levels.

\section{Rutin, Rutinosidase and Quercetin}

Flavonoids and their glycosides represent one of the major classes of plant secondary metabolites. These are widely distributed natural compounds of special interest, due to their antioxidant properties and their potential in the prevention of tiredness, diabetes mellitus, oxidative stress and Parkinson's disease [6,12-15]. Flavonoids are a group of plant-derived phenolic compounds, with a 15-carbon skeleton, made up of two benzene rings and bound to a heterocyclic pyrone ring. Rutin (i.e., $3^{\prime}, 4^{\prime}, 5,7$-tetrahydroxy-flavone-3-rutinoside) is a flavonol glycoside that has received much attention due to its antimicrobial, anti-inflammatory, anticancer and antidiabetic properties $[6,16,17]$, while quercetin is an aglycone formed after enzymatic degradation of rutin by rutinosidase. Orally admistered quercetin is able to cross the blood-brain barrier and accumulate in brain tissue [17].

One of the functions of rutin in buckwheat plants is protection of the plant organs from solar ultraviolet (UV) radiation $[18,19]$. In addition, quercetin derivatives were detected among the main bioactive substances in buckwheat root exudates, protecting buckwheat plants from weeds [20,21]. Exposure of buckwheat grain to moisture results in enzymatic breakdown of rutin to quercetin by rutinosidase (Figure 1), as happens also after milling and mixing of the flour with water [19,22-25]. Vombergar [25] simulated the procedure of dough and bread making from Tartary buckwheat flour, by mixing $66 \%$ of flour and $44 \%$ of water. The mixture was covered to maintain the moisture and was stored at $20^{\circ} \mathrm{C}$ for $0.08,0.5,1$, respectively, for 24 hours. After the given time of storage the concentration of rutin and quercetin was measured by high-performance liquid chromatography (HPLC). Within first $5 \mathrm{~min}(0.08 \mathrm{~h})$ most of rutin was degraded, and quercetin appeared in the flour/water mixture. The concentration of quercetin was after that stable for at least 24 hours (Figure 1 ). 


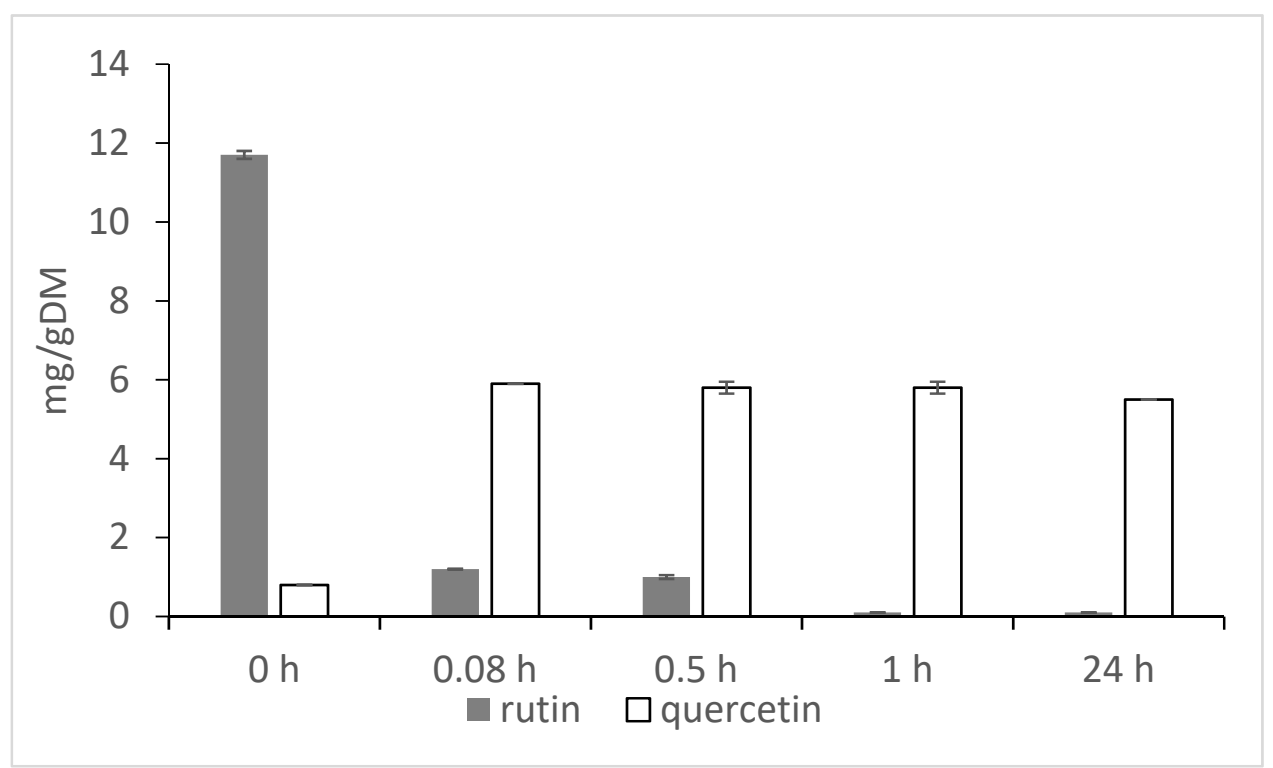

Figure 1. Rutin transformation to quercetin in buckwheat flour under condition of $44 \%$ water in the mixture [25].

Common and Tartary buckwheat grain and leaves are important sources of rutin [6,26-30] and food products like bread, groats, noodles and pancakes [11]. In humans, products derived from common and Tartary buckwheat grain have been shown to reduce fatigue symptoms, decrease blood cholesterol levels, and improve lung capacity [12,13,31-33]. Buckwheat grain methanol extracts can also protect DNA from damage caused by hydroxyl radicals, as was demonstrated for a human hepatoma cell line [34]. These DNA-protecting effects of buckwheat extracts have been associated with high levels of rutin and quercetin, although other substances in buckwheat extracts might also have roles [6,34]. Rutin-derived quercetin is also a stronger inhibitor of aflatoxin synthesis in grain by Aspergillus flavus, compared to rutin [35].

A new Tartary buckwheat variety with lower rutinosidase activity was recently bred in Japan [36-40]. The motivation for this was to produce Tartary-buckwheat-based food products (e.g., bread, noodles) that contain considerably more rutin than quercetin, in order to achieve more acceptable foods (i.e., less bitter) from Tartary buckwheat [41-45]. Furthermore, the consumption of rutin-rich foods offers a feasible approach for the improvement of human nutrition, due to the known protective health effects of rutin. This has now also become especially important because of its antiviral activity, including its reported activity against the Sars-CoV-2 virus [46,47]. Buckwheat is a promising source of rutin, the inhibitor of main protease and other protein targets of Sars-CoV-2 virus [48-50].

Tartary buckwheat with low rutinosidase activity may become more popular in countries where foods made from Tartary buckwheat are generally less popular than those made from common buckwheat. This can occur because the less-bitter buckwheat products are preferred by consumers, which is especially the case in Japan, where consumers are used to non-bitter buckwheat noodles. For markets where consumers prefer the 'gentler' taste of common and Tartary buckwheat dishes, the backcrossing of Tartary buckwheat varieties with the new low-rutinosidase Tartary buckwheat variety would represent an important tool to provide foods with high content of flavonoids, but without a bitter taste.

Another way to prevent degradation of rutin to quercetin is to scald Tartary buckwheat flour with water and keep it wet for $20 \mathrm{~min}$ at the temperature $80-95^{\circ} \mathrm{C}$ [51]. This process helps to conserve more of the rutin in the flour, which results in higher levels of rutin in the final product, such as bread or noodles [51-53]. In addition, a lot of the rutin in common and Tartary buckwheat is stored in the embryo. Therefore, breeding of buckwheat with the aim of producing larger embryos may be a 
promising strategy for increasing the levels of rutin in common and Tartary buckwheat grain (Figure 2, Table 1) [11].

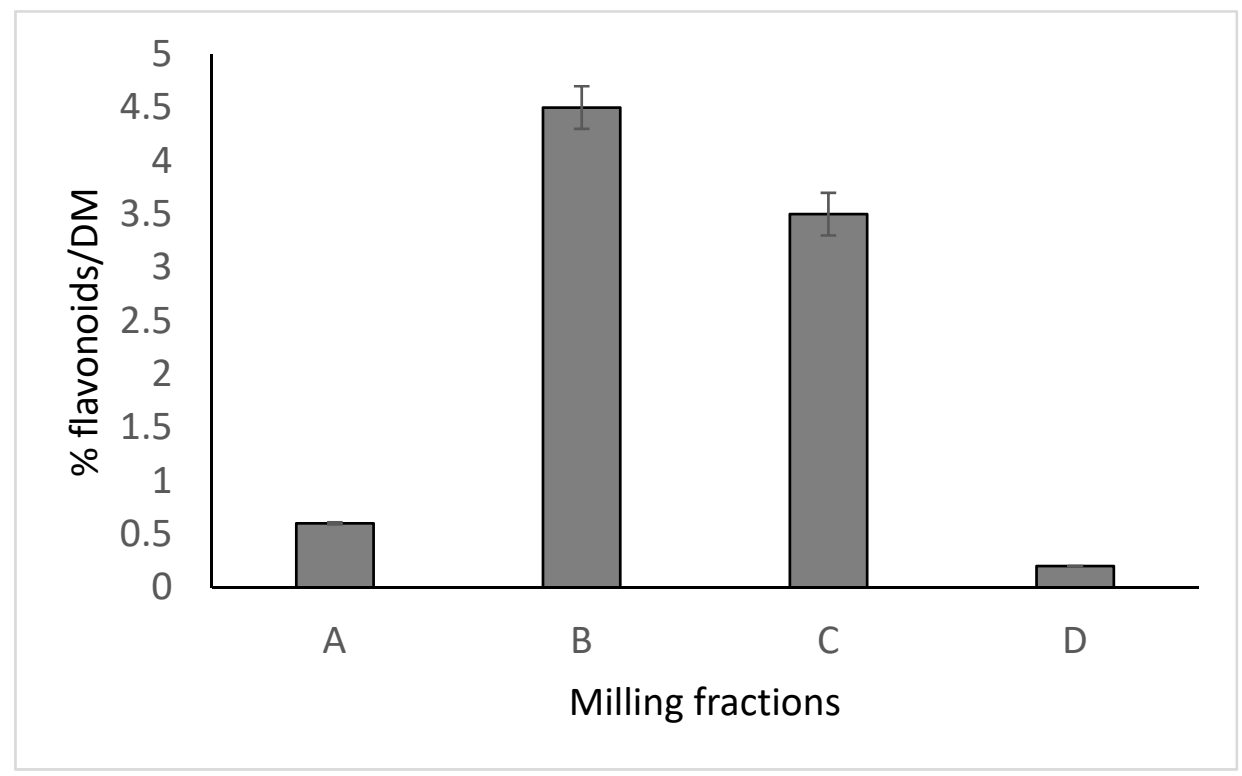

Figure 2. Distribution of flavonoids among Tartary buckwheat milling fractions.

Rutin and quercetin are of similar importance from the point of view of impact to human body $[54,55]$. However, the enhancement of rutin content in buckwheat grain is of great importance to avoid the bitter taste of quercetin [41-43].

Table 1. Rutin and quercetin content in common and Tartary buckwheat grain and products (in $\mathrm{g} / 100 \mathrm{~g}$ dry matter).

\begin{tabular}{ccccc}
\hline Species & Sample & Rutin & Quercetin & Literature Source \\
\hline Tartary buckwheat & Flour & 1.46 & 0.19 & {$[52]$} \\
Tartary buckwheat & Bread & & 0.51 & {$[52]$} \\
Tartary buckwheat & Herb & $1.2-3.1$ & & {$[56]$} \\
Tartary buckwheat & Grain & $1.3-1.6$ & & {$[56]$} \\
Common buckwheat & Grain & 0.01 & & {$[56]$} \\
Common buckwheat & Flour & 0.0003 & & {$[23]$} \\
Tartary buckwheat & Wholemeal flour & 0.22 & 0.19 & {$[57]$} \\
Tartary buckwheat & Malt from wholemeal flour & 0.37 & 0.41 & {$[57]$} \\
Tartary buckwheat & Flour & 1.17 & 0.06 & {$[25]$} \\
Tartary buckwheat & Flour & $1.584-1.637$ & & {$[42]$} \\
Common buckwheat & Grain & $0.017-0.070$ & & {$[58,59]$} \\
\hline
\end{tabular}

Vombergar et al. [60] performed milling, sieving and analysing experiments with Tartary buckwheat grain (Figure 2). Among milling fractions, the highest concentration of flavonoids in Tartary buckwheat flour (granulation over $100 \mu \mathrm{m}$ up to including $1000 \mu \mathrm{m}$ ) was established as $3.5-4.5 \%$ flavonoids in dry matter. This was a milling fraction of dark coarse flour, containing parts of milled grain embryo. Knowledge about the distribution of flavonoids among milling fractions, in relation to the size of the particles, is important in obtaining flavonoid-rich milling fractions of high nutritional relevance [60].

A, flour, granulation $\leq 100 \mu \mathrm{m}$; B, flour, granulation $100 \mu \mathrm{m}<\mathrm{x} \leq 236 \mu \mathrm{m}$, including embryo particles; C, flour, granulation $236 \mu \mathrm{m}<\mathrm{x} \leq 1000 \mu \mathrm{m}$; D, flour, granulation $>1000 \mu \mathrm{m}$, including bran and husk [60]. 
The novel Tartary buckwheat variety with low rutinosidase activity also shows no $\alpha$-glucosidase inhibition, while the traditional Tartary buckwheat varieties are characterised by higher levels of $\alpha$-glucosidase inhibitory activity [36,61]. Indeed, in Tartary buckwheat grain, quercetin originating from rutin degradation has been reported to be responsible for $\alpha$-glucosidase inhibitory activity [14]. This is important for mitigation of the diabetes mellitus condition [14,61-63]. High rutin and low quercetin buckwheat products are important only for some customers, for example consumers of soba (buckwheat) noodles in Japan. On other hand, European customers, accepting some bitter dishes, may have the benefit of mitigation of the diabetes mellitus condition by the $\alpha$-glucosidase inhibitory activity of quercetin [14].

\section{Fagopyrin and Emodin}

Fagopyrin is another secondary metabolite that is found in the green plant parts (e.g., sprouts, leaves) and less so in the grain [64-66]. Six fagopyrin derivatives were identified in three species of Fagopyrum (i.e., F. esculentum, F. tataricum, F. cymosum), as fagopyrins A to F [10,67]. The highest fagopyrin levels have been reported for F. cymosum flowers, at $20.7 \mathrm{mg} / \mathrm{g}$ dry weight, with high levels also found in common buckwheat flowers and leaves, at $\leq 4.83 \mathrm{mg} / \mathrm{g}$ and 0.32 to $2.3 \mathrm{mg} / \mathrm{g}$, respectively [66].

The levels of fagopyrin are at their highest during seed germination, and light is important for the transformation of protofagopyrins to fagopyrins, as increased fagopyrin levels have been shown to accompany increased light conditions $[10,67,68]$. Fagopyrin is involved in the regulation of the mycelial growth, morphology and pathogenicity of fungi [69]. The consumption of large quantities of the green parts of buckwheat plants can also provoke fagopyrism, a condition of photosensitisation that can cause skin irritation, oedema and a serous exudate. In buckwheat grain, however, fagopyrin levels are lower than those of other antioxidative compounds, thus avoiding these negative effects on human health [10].

The potential to reduce fagopyrin levels in buckwheat by plant breeding has not been assessed to date. However, as fagopyrin appears to have a role in the protection of plants against UV radiation, pests and/or diseases, breeding for varieties with reduced fagopyrin levels might result in collateral, undesired, effects for plants grown in high UV environments.

Emodin (i.e., 6-methyl-1,3,8-trihydroxyanthraquinone) is another buckwheat metabolite that has structural similarity to metabolites from the group of naphthodianthrones. It is believed to be a precursor of hypericin [70], and possibly also the precursor of fagopyrin. Emodin isolated from Tartary buckwheat grain [71] has been shown to bind well to all three active sites of the RNA binding domain of the nucleocapsid phosphoprotein of Sars-CoV-2 [70,72,73]. However, the biosynthesis pathways of emodin in Tartary buckwheat remain unclear to date [74]. Emodin has been detected in Tartary buckwheat bran and leaves, but not in the roots [71]. Molecular modelling has suggested that hypericin can interact with HIV-1 protease [75], although further studies of the antiviral effects of fagopyrin and/or buckwheat metabolites resembling hypericin still need to be performed.

\section{Buckwheat Breeding: Challenges and Prospects for the Future}

The breeding methods for common and Tartary buckwheat differ considerably. Tartary buckwheat is self-compatible, while common buckwheat is an obligatory cross-fertilising plant. Large numbers of the original domestic buckwheat varieties can still be found in countries with a long tradition of buckwheat cultivation and consumption. In particular, wild relatives of common and Tartary buckwheat can be found in the Himalayas, where the Fagopyrum genus originated.

To breed buckwheat varieties with agronomically and nutritionally improved characteristics, it is important to collect as much of the available genetic material as possible, and to store it appropriately. Due to the wide phenotypic and genetic heterogeneity of common buckwheat [76,77], the search for valuable but recessive genes in this heterozygous plant will be challenging, but will also be worth the 
effort both scientifically and commercially. In common buckwheat, it is possible to reveal properties under the control of recessive genes in the progeny after crossing sister plants.

Breeding of common buckwheat is difficult because of a single gene complex S-locus, which controls self-incompatibility, as it is tied to favorable weather conditions during flowering, which influence the presence of pollinators [78-80]. An optimally designed breeding program includes an appropriate initial pin/thrum ratio of parent plants in favor of thrum plants. In buckwheat, nectar production can be influenced by heteromorphy, ploidy level, plant age, inflorescence position and abiotic factors. Except for the morphology of the reproductive organs, both morphs differ in nectar production. Thrum flowers or plants produce up to $30 \%$ more nectar than pin flowers during the first half part of the flowering [81]. Pollination efficiency depends on many factors: a plant's capacity to attract pollinators by flower morphology, and by pollen and nectar production on the insect (honeybee) abundance and ability to collect, transport, and deposit pollen on a compatible stigma. Apart from pollinator-related pollination, common buckwheat is very sensitive to climatic factors, sowing date, photoperiod sensitivity and local agronomic practices that have a strong impact on yield of seeds. Abiotic factors like weather conditions, drought, solar radiation, weeds and available nutrients may affect the development and yield of buckwheat plants [81-83]. Some of the important breeding objectives in common buckwheat breeding include stable yield, superior seed quality, lodging resistance, determinate growth habit, easy dehulling, low shattering of seeds, flood resistance, rutin content, low allergenic protein content, good aroma, and pre-harvest sprouting resistance $[2,4,5,58,59,84,85]$.

In contrast to common buckwheat, Tartary buckwheat is homozygous, which essentially means that Tartary buckwheat populations are more conserved and that there are no 'hidden genes' in the population. Indeed, being homozygous, Tartary buckwheat populations consist of plants that produce genetically identical progeny. In domestic populations of Tartary buckwheat, there are inbred lines that can differ in terms of specific characteristics, including the levels of desired metabolites and also the crop yield, easy dehulling, low shattering seeds [86]. Thus, the metabolite levels are not the sole criterion for selection. Both the grain yield per unit area and the yield of metabolites per unit area are of paramount importance. Certainly, for extraction and isolation of a metabolite in the pharmaceutical industry (e.g., rutin), it is important to reach high plant levels of the metabolite, to minimise the harvested plant material needed, and to optimise the extraction, isolation and concentration of the desired metabolite $[5,87,88]$.

In chemical analyses of mixtures of Tartary buckwheat seeds, it is not easy to find genotypes with specific desired properties and an appropriate metabolite layout in such bulk material. What is needed is the analysis of seeds from individual plants, or from genetically identical sister plants. Otherwise any outstanding (and potentially desired) properties of individual outliers would be masked by the impact of the metabolite concentrations of the plants of average quality $[84,89]$.

Tartary buckwheat can by ploidy induction be effectively transformed to the tetraploid level by colchicine or other cytostatics. In comparison to the diploid plants, various agronomic traits may be increased in the induced tetraploid plants, including seed size, 1000-seed mass, leaf size, chlorophyll content, flower size and pollen diameter. The content of seed protein and flavonoid may also be increased in the tetraploid plants. It is very important to choose a genotype with a high yield and easily shelled traits before polyploidization $[90,91]$. Perennial buckwheat development could be an interesting challenge in buckwheat breeding [87].

Tissue culture techniques can be applied to the breeding of common and Tartary buckwheat. Using in vitro tissue culture, whole genetically identical plants can be regenerated from a single cotyledon [92-95], a hypocotyl [96,97] or a meristem [98]. In this way, haploids of common buckwheat have already been generated $[99,100]$. However, the success rate of regeneration is low and greatly depends on the genotype [94]. Therefore, it will be necessary to develop rapid and easy procedures with high regeneration rates and reproducibility. Interspecies hybrids can also be successfully obtained by rescuing immature embryos [101,102]. Such haploids would allow the breeding of hybrids, although the procedures for obtaining haploids in buckwheat have not yet been optimised. Furthermore, 
the regeneration of buckwheat plants from tissue cultures is limited by the high levels of phenolic substances in common and Tartary buckwheat tissues (Figure 3).

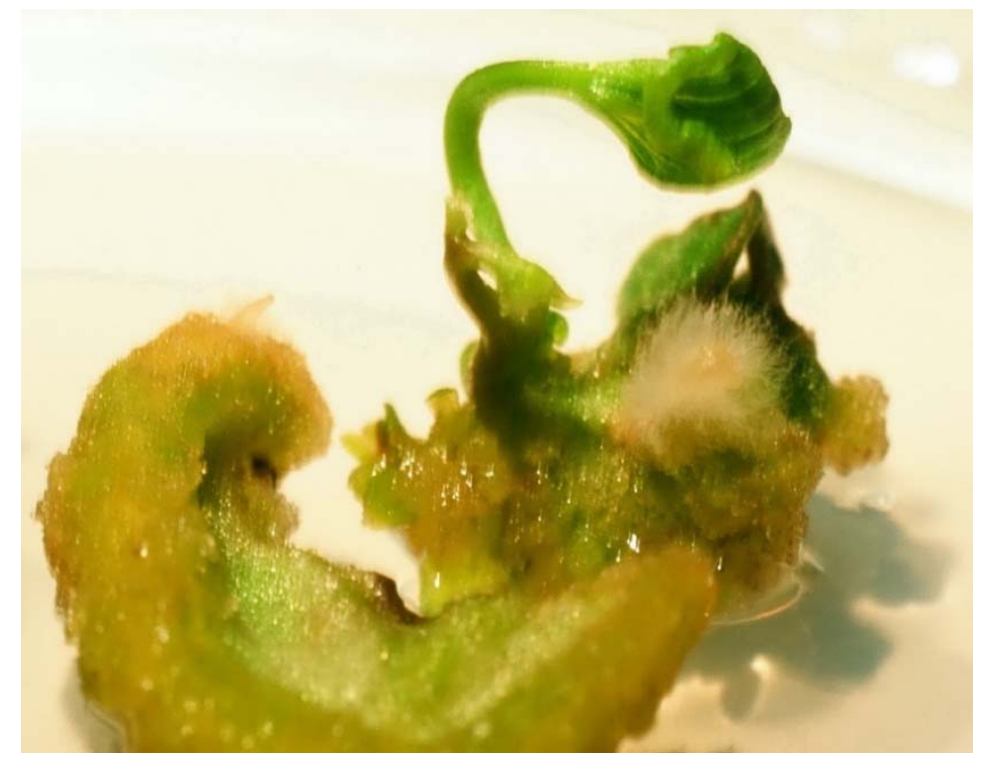

Figure 3. Common buckwheat cotyledons can be used in tissue culture techniques to regenerate several progeny plants with an identical genotype.

However, interspecies hybrids within the genus Fagopyrum and their resulting alloploids [103] represent good sources for breeding, to obtain plants with large grain embryos and promising flavonoid and emodin levels.

\section{Conclusions}

Common buckwheat and Tartary buckwheat grain contain the bioactive compounds rutin, quercetin, emodin and fagopyrin with potential antiviral effects. Rutin, a flavonol glycoside is important because of its reported antimicrobial, anti-inflammatory and anticancer properties. Quercetin is an aglycone formed after enzymatic degradation of rutin by rutinosidase. In addition to the properties of rutin, it has been reported that the antidiabetic effects of quercetin are related to its $\alpha$-glucosidase inhibitory activity. This is important for the mitigation of diabetes mellitus. In Tartary buckwheat grain, quercetin originating from rutin degradation is responsible for the bitter taste of products and foods. The prevention of rutin degradation to quercetin is important for customers, especially in Asian countries, who are not familiar with the bitter taste of buckwheat dishes. In contrast, customers who accept bitter dishes, can benefit from the mitigation of a diabetes mellitus condition by the $\alpha$-glucosidase inhibiting effect of quercetin.

Fagopyrin, a naphthodianthrone, is involved in the regulation of mycelial growth, the morphology and pathogenicity of fungi, and in the protection of plants against UV radiation. Consumption of considerable amounts of the green parts of buckwheat plants can also cause fagopyrism, photosensitisation with skin irritation and edema. However, the content of fagopyrin is lower than those of other antioxidative compounds, thus avoiding the negative effects of fagopyrin on human health. Emodin, with structural similarity to metabolites from the group of naphthodianthrones, isolated from Tartary buckwheat grain has been shown to bind well to the active sites of the RNA binding domain of the nucleocapsid phosphoprotein of Sars-CoV-2. Emodin was detected in Tartary buckwheat leaves and bran. Its bioactivity should be further investigated.

The breeding objectives of buckwheat include stable yields, superior seed quality, lodging resistance, determinate growth habit, easy dehulling, low shattering of seeds, flood resistance, rutin content, low allergenic protein content, good aroma, and pre-harvest sprouting resistance. Breeding 
buckwheat to obtain plants with large grain embryos is a promising method to obtain genotypes with high flavonoid and emodin content.

Author Contributions: Conceptualisation, Z.L., P.P., K.V.-M., I.K.; data curation, M.G., M.L., A.G.; validation, writing original draft preparation, review and editing, all authors equally responsible; visualisation, A.G., I.K.; supervision, I.P.; project administration, M.G., A.K.; funding acquisition, I.K., A.K., I.P. All authors have read and agreed to the published version of the manuscript.

Funding: This work was the result of a study financed by the Slovenian Research Agency, through the programmes P1-0212 "Biology of Plants" and P3-0395 "Nutrition and Public Health", and the applied project L4-9305, co-financed by the Ministry of Agriculture, Forestry and Food, Republic of Slovenia.

Acknowledgments: The authors are grateful for the collaboration with Christian Zewen, Luxemburg, and to Christopher Berrie for revising the English text.

Conflicts of Interest: The authors declare that they have no conflict of interest.

\section{References}

1. Wei, Y.M. Buckwheat remains from the late Neolithic site of Donghuishan, Gansu Province, China. Cereal Chem. 2019, 96, 332-337. [CrossRef]

2. Ohsawa, R. Current status and prospects of common buckwheat breeding in Japan. Breed. Sci. 2020, 70, 3-12. [CrossRef] [PubMed]

3. Ruiz, Y.L.B.; Scott, I.M.; McNeil, J.N. The buckwheat effect: A biopesticide for Wireworm? J. Econ. Entomol. 2019, 112, 625-632. [CrossRef] [PubMed]

4. Morishita, T.; Hara, T.; Hara, T. Important agronomic characteristics of yielding ability in common buckwheat; ecotype and ecological differentiation, preharvest sprouting resistance, shattering resistance, and lodging resistance. Breed. Sci. 2020, 70, 39-47. [CrossRef] [PubMed]

5. Singh, M.; Malhotra, N.; Sharma, K. Buckwheat (Fagopyrum sp.) genetic resources: What can they contribute towards nutritional security of changing world? Genet. Resour. Crop Evol. 2020, 67, 1639-1658. [CrossRef]

6. Kreft, M. Buckwheat phenolic metabolites in health and disease. Nutr. Res. Rev. 2016, 29, 30-39. [CrossRef]

7. Pongrac, P.; Kelemen, M.; Vavpetič, P.; Vogel-Mikuš, K.; Regvar, M.; Pelicon, P. Application of micro-PIXE (particle induced $X$-ray emission) to study buckwheat grain Structure and Composition. Fagopyrum 2020, 37, 5-10. [CrossRef]

8. Sytar, O.; Svediene, J.; Loziene, K.; Paskevicius, A.; Kosyan, A.; Taran, N. Antifungal properties of hypericin, hypericin tetrasulphonic acid and fagopyrin on pathogenic fungi and Spoilage yeasts. Pharm. Biol. 2016, 54, 3121-3125. [CrossRef]

9. Skrabanja, V.; Kreft, I. Resistant starch formation following autoclaving of buckwheat (Fagopyrum esculentum Moench) groats. An in vitro study. J. Agric. Food Chem. 1998, 46, 2020-2023. [CrossRef]

10. Huda, M.N.; Lu, S.; Jahan, T.; Ding, M.; Jha, R.; Zhang, K.; Zhang, W.; Georgiev, M.I.; Park, S.U.; Zhou, M. Treasure from garden: Bioactive compounds of buckwheat. Food Chem. 2020, 335, 127653. [CrossRef]

11. Kreft, I.; Zhou, M.L.; Golob, A.; Germ, M.; Likar, M.; Dziedzic, K.; Luthar, Z. Breeding Buckwheat for Nutritional Quality. Breed. Sci. 2020, 70, 67-73. [CrossRef]

12. Wieslander, G.; Fabjan, N.; Vogrinčič, M.; Kreft, I.; Janson, C.; Spetz-Nystrom, U.; Vombergar, B.; Tagesson, C.; Leanderson, P.; Norbäck, D. Eating buckwheat cookies is associated with the reduction in serum levels of myeloperoxidase and cholesterol: A double blind crossover study in day-care centre staffs. Tohoku J. Exp. Med. 2011, 225, 123-130. [CrossRef] [PubMed]

13. Wieslander, G.; Fabjan, N.; Vogrinčič, M.; Kreft, I.; Vombergar, B.; Norbäck, D. Effects of common and Tartary buckwheat consumption on mucosal symptoms, headache and tiredness: A double-blind crossover intervention study. J. Food Agric. Environ. 2012, 10, 107-110.

14. Ikeda, K.; Ishida, Y.; Ikeda, S.; Asami, Y.; Lin, R. Tartary, but not common, buckwheat inhibits $\alpha$-glucosidase activity: Its nutritional implications. Fagopyrum 2017, 34, 13-18. [CrossRef]

15. Zhang, C.N.; Zhang, R.; Li, Y.M.; Liang, N.; Zhao, Y.M.; Zhu, H.Y.; He, Z.Y.; Liu, J.H.; Hao, W.J.; Jiao, R.; et al. Cholesterol-lowering activity of Tartary buckwheat protein. J. Agric. Food Chem. 2017, 65, 1900-1906. [CrossRef] [PubMed] 
16. Gullon, B.; Lu-Chau, T.A.; Moreira, M.T.; Lema, J.M.; Eibes, G. Rutin: A review on extraction, Identification and Purification Methods, Biological Activities and Approaches to enhance its bioavailability. Trends Food Sci. Technol. 2017, 67, 220-235. [CrossRef]

17. Kawabata, K.; Mukai, R.; Ishisaka, A. Quercetin and related polyphenols: New insights and implications for their bioactivity and bioavailability. Food Funct. 2015, 6, 1399-1417. [CrossRef]

18. Kreft, S.; Štrukelj, B.; Gaberščik, A.; Kreft, I. Rutin in buckwheat herbs grown at different UV-B radiation levels: Comparison of two UV spectrophotometric and an HPLC method. J. Exp. Bot. 2002, 53, 1801-1804. [CrossRef]

19. Suzuki, T.; Honda, Y.; Mukasa, Y. Effects of UV-B radiation, cold and desiccation stress on rutin concentration and rutin glucosidase activity in Tartary buckwheat (Fagopyrum tataricum) leaves. Plant Sci. 2005, 168, 1303-1307. [CrossRef]

20. Kalinova, J.; Vrchotova, N.; Triska, J. Exudation of allelopathic substances in buckwheat (Fagopyrum esculentum Moench). J. Agric. Food Chem. 2007, 55, 6453-6459. [CrossRef]

21. Gfeller, A.; Glauser, G.; Etter, C.; Signarbieux, C.; Wirth, J. Fagopyrum esculentum alters its root exudation after Amaranthus retroflexus recognition and suppresses weed growth. Front. Plant Sci. 2018, 9. [CrossRef] [PubMed]

22. Yasuda, T.; Nakagawa, H. Purification and characterization of the rutin-degrading enzymes in Tartary buckwheat seeds. Phytochemistry 1994, 37, 133-136. [CrossRef]

23. Suzuki, T.; Honda, Y.; Mukasa, Y.; Kim, S. Effects of lipase, lipoxygenase, peroxidase, and rutin on quality deteriorations in buckwheat flour. J. Agric. Food Chem. 2005, 53, 8400-8405. [CrossRef]

24. Fujita, K.; Yoshihashi, T. Heat-treatment of Tartary buckwheat (Fagopyrum tataricum Gaertn.) provides dehulled and gelatinized product with denatured rutinosidase. Food Sci. Technol. Res. 2019, 25, $613-618$. [CrossRef]

25. Vombergar, B. Rutin and quercetin in common buckwheat and Tartary buckwheat flour. Folia Biol. Geol. 2020, 61, 257-280. [CrossRef]

26. Gaberščik, A.; Vončina, M.; Trošt, T.; Germ, M.; Björn, L.O. Growth and production of buckwheat (Fagopyrum esculentum) treated with reduced, ambient, and enhanced UV-B radiation. J. Photochem. Photobiol. B 2002, 66, 30-36. [CrossRef]

27. Holasova, M.; Fiedlerova, V.; Smrcinova, H.; Orsak, M.; Lachman, J.; Vavreinova, S. Buckwheat-The source of antioxidant activity in functional foods. Food Res. Int. 2002, 35, 207-211. [CrossRef]

28. Matsui, K.; Oshima, Y.; Mitsuda, N.; Sakamoto, S.; Nishiba, Y.; Walker, A.R.; Ohme-Takagi, M.; Robinson, S.P.; Yasui, Y.; Mori, M.; et al. Buckwheat R2R3 MYB transcription factor FeMYBF1 regulates flavonol biosynthesis. Plant Sci. 2018, 274, 466-475. [CrossRef]

29. Kalinova, J.P.; Vrchotova, N.; Triska, J. Phenolics levels in different parts of common buckwheat (Fagopyrwn esculentum) achenes. J. Cereal Sci. 2019, 85, 243-248. [CrossRef]

30. Zhang, K.X.; Logacheva, M.D.; Meng, Y.; Hu, J.P.; Wan, D.P.; Li, L.; Janovska, D.; Wang, Z.Y.; Georgiev, M.I.; $\mathrm{Yu}, \mathrm{Z}$; et al. Jasmonate-responsive MYB factors spatially repress rutin biosynthesis in Fagopyrum tataricum. J. Exp. Bot. 2018, 69, 1955-1966. [CrossRef]

31. Sikder, K.; Kesh, S.B.; Das, N.; Manna, K.; Dey, S. The high antioxidative power of quercetin (aglycone flavonoid) and its glycone (rutin) avert high cholesterol diet induced hepatotoxicity and inflammation in swiss albino mice. Food Funct. 2014, 5, 1294-1303. [CrossRef] [PubMed]

32. Yang, N.; Li, Y.M.; Zhang, K.S.; Jiao, R.; Ma, K.Y.; Zhang, R.; Ren, G.X.; Chen, Z.Y. Hypocholesterolemic activity of buckwheat flour is mediated by increasing sterol excretion and down-regulation of intestinal NPC1L1 and ACAT2. J. Funct. Foods 2014, 6, 311-318. [CrossRef]

33. Vogrinčič, M.; Timoracka, M.; Melichacova, S.; Vollmannova, A.; Kreft, I. Degradation of rutin and polyphenols during the preparation of Tartary buckwheat bread. J. Agric. Food Chem. 2010, 58, 4883-4887. [CrossRef] [PubMed]

34. Vogrinčič, M.; Kreft, I.; Filipič, M.; Žegura, B. Antigenotoxic Effect of Tartary (Fagopyrum tataricum) and common (Fagopyrum esculentum) buckwheat flour. J. Med. Food 2013, 16, 944-952. [CrossRef] [PubMed]

35. Chitarrini, G.; Nobili, C.; Pinzari, F.; Antonini, A.; De Rossi, P.; Del Fiore, A.; Procacci, S.; Tolaini, V.; Scala, V.; Scarpari, M.; et al. Buckwheat achenes antioxidant profile modulates Aspergillus flavus growth and aflatoxin production. Int. J. Food Microbiol. 2014, 189, 1-10. [CrossRef] 
36. Suzuki, T.; Honda, Y.; Funatsuki, W.; Nakatsuka, K. Purification and characterization of flavonol 3-glucosidase, and its activity during ripening in Tartary buckwheat seeds. Plant Sci. 2002, 163, 417-423. [CrossRef]

37. Suzuki, T.; Morishita, T.; Mukasa, Y.; Takigawa, S.; Yokota, S.; Ishiguro, K.; Noda, T. Breeding of 'Manten-Kirari', a non-bitter and trace-rutinosidase variety of Tartary Buckwheat (Fagopyrum tataricum Gaertn.). Breeding Sci. 2014, 64, 344-350. [CrossRef]

38. Suzuki, T.; Morishita, T.; Kim, S.J.; Park, S.U.; Woo, S.H.; Noda, T.; Takigawa, S. Physiological roles of rutin in the buckwheat plant. Jarq-Jpn. Agric. Res. Q. 2015, 49, 37-43. [CrossRef]

39. Suzuki, T.; Morishita, T.; Noda, T.; Ishiguro, K. Acute and subacute toxicity studies on rutin-rich Tartary buckwheat dough in experimental animals. J. Nutr. Sci. Vitaminol. 2015, 61, 175-181. [CrossRef]

40. Suzuki, T.; Morishita, T.; Takigawa, S.; Noda, T.; Ishiguro, K. Characterization of rutin-rich bread made with 'Manten-Kirari', a trace-rutinosidase variety of Tartary buckwheat (Fagopyrum tataricum Gaertn.). Food Sci. Technol. Res. 2015, 21, 733-738. [CrossRef]

41. Jin, H.R.; Yu, J.; Choi, S.J. Hydrothermal treatment enhances antioxidant activity and intestinal absorption of rutin in Tartary buckwheat flour extracts. Foods 2020, 9, 8. [CrossRef] [PubMed]

42. Dziedzic, K.; Górecka, D.; Szwengiel, A.; Olejnik, A.; Rychlik, J.; Kreft, I.; Drożdżyńska, A.; Walkowiak, J. The cytotoxic effect of artificially digested buckwheat products on HT-29 colon cancer cells. J. Cereal Sci. 2018, 83, 68-73. [CrossRef]

43. Sun, Y.L.; Zhou, W.M.; Huang, Y.G. Encapsulation of Tartary buckwheat flavonoids and application to yoghurt. J. Microencapsul. 2020, 37, 445-456. [CrossRef] [PubMed]

44. Levit, A.; Nowak, S.; Peters, M.; Wiener, A.; Meyerhof, W.; Behrens, M.; Niv, M.Y. The bitter pill: Clinical drugs that activate the human bitter taste receptor TAS2R14. FASEB J. 2013, 28, 1181-1197. [CrossRef] [PubMed]

45. Duarte, A.C.; Santos, J.; Costa, A.R.; Ferreira, C.L.; Tomas, J.; Quintela, T.; Ishikawa, H.; Schwerk, C.; Schroten, H.; Ferrer, I.; et al. Bitter taste receptors profiling in the human blood-cerebrospinal fluid-barrier. Biochem. Pharmacol. 2020, 177, 113954. [CrossRef]

46. Shawky, E.; Nada, A.A.; Ibrahim, R.S. Potential role of medicinal plants and their constituents in the mitigation of Sars-Cov-2: Identifying related therapeutic targets using network pharmacology and molecular docking analyses. RSC Adv. 2020, 10, 27961-27983. [CrossRef]

47. Das, P.; Majumder, R.; Mandal, M.; Basak, P. In-silico approach for identification of effective and stable inhibitors for Covid-19 main protease (M-pro) from flavonoid based phytochemical constituents of Calendula officinalis. J. Biomol. Struct. Dyn. 2020. [CrossRef]

48. Al-Zahrani, A.A. Rutin as a promising inhibitor of main protease and other protein targets of Covid-19: In silico study. Nat. Prod. Commun. 2020, 15. [CrossRef]

49. Bhowmik, D.; Nandi, R.; Jagadeesan, R.; Kumar, N.; Prakash, A.; Kumar, D. Identification of potential inhibitors against Sars-Cov-2 by targeting proteins responsible for envelope formation and virion assembly using docking based virtual screening, and pharmacokinetics approaches. Infect. Genet. Evol. 2020, 84, 1-14. [CrossRef]

50. Shivanika, C.; Kumar, S.D.; Ragunathan, V.; Tiwari, P.; Sumitha, A.; Devi, P.B. Molecular docking, validation, dynamics simulations, and pharmacokinetic prediction of natural compounds against the Sars-Cov-2 main-protease. J. Biomol. Struct. Dyn. 2020, 83, 1-28. [CrossRef]

51. Germ, M.; Arvay, J.; Vollmannova, A.; Toth, T.; Golob, A.; Luthar, Z.; Kreft, I. The temperature threshold for the transformation of rutin to quercetin in Tartary buckwheat dough. Food Chem. 2019, 283, 28-31. [CrossRef]

52. Lukšič, L.; Bonafaccia, G.; Timoracka, M.; Vollmannova, A.; Trček, J.; Nyambe, T.K.; Melini, V.; Acquistucci, R.; Germ, M.; Kreft, I. Rutin and quercetin transformation during preparation of buckwheat sourdough bread. J. Cereal Sci. 2016, 69, 71-76. [CrossRef]

53. Brajčič, F.; Luštek, P.; Šuštarič, T.; Pust, J. Extraction of rutin and quercetin from Tartary buckwheat grains, hydrothermally treated at different temperatures. Fagopyrum 2020, 37, 37-40. [CrossRef]

54. Braune, A.; Blaut, M. Bacterial Species Involved in the conversion of dietary flavonoids in the human gut. Gut Microbes 2016, 7, 216-234. [CrossRef] [PubMed]

55. Shin, N.R.; Moon, J.S.; Shin, S.Y.; Li, L.; Lee, Y.B.; Kim, T.J.; Han, N.S. Isolation and characterization of human intestinal enterococcus avium EFEL009 converting rutin to quercetin. Lett. Appl. Microbiol. 2016, 62, 68-74. [CrossRef] [PubMed] 
56. Fabjan, N.; Rode, J.; Košir, I.J.; Wang, Z.H.; Zhang, Z.; Kreft, I. Tartary buckwheat (Fagopyrum tataricum Gaertn.) as a source of dietary rutin and quercitrin. J. Agric. Food Chem. 2003, 51, 6452-6455. [CrossRef]

57. Molinari, R.; Costantini, L.; Timperio, A.M.; Lelli, V.; Bonafaccia, F.; Bonafaccia, G.; Merendino, N. Tartary buckwheat malt as igredient of gluten-free cookies. J. Cereal Sci. 2018, 80, 37-43. [CrossRef]

58. Suzuki, T.; Hara, T.; Hara, T.; Katsu, K. Effect of storage temperature on occurrence of secondary dormancy in buckwheat Seeds. Seed Sci. Technol. 2020, 48, 257-267. [CrossRef]

59. Suzuki, T.; Noda, T.; Morishita, T.; Ishiguro, K.; Otsuka, S.; Brunori, A. Present status and future perspectives of breeding for buckwheat quality. Breed. Sci. 2020, 70, 48-66. [CrossRef]

60. Vombergar, B.; Škrabanja, V.; Germ, M. Flavonoid concentration in milling fractions of Tartary and common buckwheat. Fagopyrum 2020, 37, 11-21. [CrossRef]

61. Ren, Q.; Liu, W.; Zhao, M.; Sai, C.M.; Wang, J.A. Changes in $\alpha$-glucosidase inhibition, antioxidant, and phytochemical profiles during the growth of Tartary buckwheat (Fagopyrum tataricum Gaertn). Int. J. Food Prop. 2018, 21, 2689-2699. [CrossRef]

62. Li, Y.Q.; Zhou, F.C.; Gao, F.; Bian, J.S.; Shan, F. Comparative evaluation of quercetin, isoquercetin and rutin as inhibitors of $\alpha$-glucosidase. J. Agric. Food Chem. 2009, 57, 11463-11468. [CrossRef] [PubMed]

63. Sharma, P.; Ghimeray, A.K.; Gurung, A.; Jin, C.W.; Rho, H.S.; Cho, D.H. Phenolic contents, antioxidant and $\alpha$-glucosidase inhibition properties of nepalese strain buckwheat vegetables. Afr. J. Biotechnol. 2012, 11, 184-190. [CrossRef]

64. Kočevar Glavač, N.; Stojilkovski, K.; Kreft, S.; Park, C.H.; Kreft, I. Determination of fagopyrins, rutin, and quercetin in Tartary buckwheat products. LWT Food Sci. Technol. 2017, 79, 423-427. [CrossRef]

65. Kreft, S.; Janež, D.; Kreft, I. The content of fagopyrin and polyphenols in common and Tartary buckwheat sprouts. Acta Pharm. 2013, 63, 553-560. [CrossRef]

66. Stojilkovski, K.; Kočevar Glavač, N.; Kreft, S.; Kreft, I. Fagopyrin and flavonoid contents in common, Tartary, and cymosum buckwheat. J. Food Compos. Anal. 2013, 32, 126-130. [CrossRef]

67. Joshi, D.C.; Zhang, K.; Wang, C.; Chandora, R.; Khurshid, M.; Li, J.; He, M.; Georgiev, M.I.; Zhou, M. Strategic enhancement of genetic gain for nutraceutical development in buckwheat: A genomics-driven perspective. Biotechnol. Adv. 2020, 39, 107479. [CrossRef]

68. Kim, J.; Hwang, K.T. Fagopyrins in different parts of common buckwheat (Fagopyrum esculentum) and Tartary buckwheat (F. tataricum) during growth. J. Food Compos. Anal. 2020, 86. [CrossRef]

69. Zambounis, A.; Sytar, O.; Valasiadis, D.; Hilioti, Z. Effect of photosensitisers on growth and morphology of Phytophthora citrophthora coupled with leaf bioassays in pear seedlings. Plant Prot. Sci. 2020, 56, 74-82. [CrossRef]

70. Rolta, R.; Yadav, R.; Salaria, D.; Sourirajan, A.; Dev, K. In silico screening of hundred phytocompounds of ten medicinal plants as potential inhibitors of nucleocapsid phosphoprotein of Covid-19: An approach to prevent virus assembly. J. Biomol. Struct. Dyn. 2020. [CrossRef]

71. Peng, L.X.; Wang, J.B.; Hu, L.X.; Zhao, J.L.; Xiang, D.B.; Zou, L.; Zhao, G. Rapid and simple method for the determination of emodin in Tartary buckwheat (Fagopyrum tataricum) by high-performance liquid chromatography coupled to a diode array detector. J. Agric. Food Chem. 2013, 61, 854-857. [CrossRef] [PubMed]

72. Robson, B. Computers and viral diseases. Preliminary bioinformatics studies on the design of a synthetic vaccine and a preventative peptidomimetic antagonist against the Sars-Cov-2 (2019-Ncov, Covid-19) coronavirus. Comput. Biol. Med. 2020, 119. [CrossRef] [PubMed]

73. Subbaiyan, A.; Ravichandran, K.; Singh, S.V.; Sankar, M.; Thomas, P.; Dhama, K.; Malik, Y.S.; Singh, R.K.; Chaudhuri, P. In silico molecular docking analysis targeting Sars-Cov-2 spike protein and selected herbal constituents. J. Pure Appl. Microbiol. 2020, 14, 989-998. [CrossRef]

74. Yin, Q.G.; Han, X.Y.; Han, Z.X.; Chen, Q.F.; Shi, Y.H.; Gao, H.; Zhang, T.Y.; Dong, G.Q.; Xiong, C.; Song, C.; et al. Genome-wide analyses reveals a glucosyltransferase involved in rutin and emodin glucoside biosynthesis in Tartary buckwheat. Food Chem. 2020, 318. [CrossRef]

75. Qu, X.B.; Su, Z.M.; Hu, D.H.; Bao, Y.L.; Meng, X.Y.; Wu, Y.; Li, Y.X. Studies on molecular structure of hypericin and its interactions with HIV-1 protease by molecular modeling. Chem. J. Chin. Univ. 2009, 30, 1402-1405.

76. Luthar, Z. Buckwheat genetic resources in Central Europe. In Buckwheat Germplasm in the World; Zhou, M., Kreft, I., Suvorova, G., Tang, Y., Woo, S.H., Eds.; Academic Press, An Imprint of Elsevier: London, UK, 2018; pp. 127-143. [CrossRef] 
77. Škrabanja, V.; Kreft, I.; Germ, M. Screening of common buckwheat genetic resources for recessive genes. In Buckwheat Germplasm in the World; Zhou, M., Kreft, I., Suvorova, G., Tang, Y., Woo, S.H., Eds.; Academic Press, An Imprint of Elsevier: London, UK, 2018; pp. 127-143. [CrossRef]

78. Mizuno, N.; Yasui, Y. Gene flow signature in the S-allele region of cultivated buckwheat. BMC Plant Biol. 2019, 19, 1-9. [CrossRef]

79. Matsui, K.; Mizuno, N.; Ueno, M.; Takeshima, R.; Yasui, Y. Development of co-dominant markers linked to a hemizygous region that is related to the self-compatibility locus (S) in buckwheat (Fagopyrum esculentum). Breed. Sci. 2020, 70, 112-117. [CrossRef]

80. Matsui, K.; Yasui, Y. Genetic and genomic research for the development of an efficient breeding system in heterostylous self-incompatible common buckwheat (Fagopyrum esculentum). Theor. Appl. Genet. 2020, 133, 1641-1653. [CrossRef]

81. Cawoy, V.; Ledent, J.F.; Kinet, J.M.; Jacquemart, A.L. Floral biology of common buckwheat (Fagopyrum esculentum Moench). Eur. J. Plant Sci. Biotechnol. 2009, 3, 1-9.

82. Yabe, S.; Hara, T.; Ueno, M.; Enoki, H.; Kimura, T.; Nishimura, S.; Yasui, Y.; Ohsawa, R.; Iwata, H. Potential of genomic selection in mass selection breeding of an allogamous crop: An empirical study to increase yield of common buckwheat. Front. Plant Sci. 2018, 9, 1-12. [CrossRef]

83. Yabe, S.; Iwata, H. Genomics-assisted breeding in minor and pseudo-cereals. Breed. Sci. 2020, 70, $19-31$. [CrossRef] [PubMed]

84. Fang, X.M.; Zhang, Y.L.; Zhang, Y.K.; Huang, K.H.; Yang, W.J.; Li, X.Y.; Zhang, Z.Y.; Wu, K.H.; Xu, X.; Ruan, R.W.; et al. De novo transcriptome assembly and identification of genes related to seed size in common buckwheat (Fagopyrum esculentum M.). Breed. Sci. 2019, 69, 487-497. [CrossRef] [PubMed]

85. Hara, T.; Shima, T.; Nagai, H.; Ohsawa, R. Genetic analysis of photoperiod sensitivity associated with difference in ecotype in common buckwheat. Breed. Sci. 2020, 70, 101-111. [CrossRef] [PubMed]

86. Zhang, L.J.; Ma, M.C.; Liu, L.L. Identification of genetic locus underlying easy dehulling in rice-Tartary for easy postharvest processing of Tartary buckwheat. Genes 2020, 11, 459. [CrossRef] [PubMed]

87. Chen, Q.F.; Huang, X.Y.; Li, H.Y.; Yang, L.J.; Cui, Y.S. Recent progress in perennial buckwheat development. Sustainability 2018, 10, 536. [CrossRef]

88. Morishita, T.; Shimizu, A.; Yamaguchi, H.; Degi, K. Development of common buckwheat cultivars with high antioxidative activity-'Gamma no irodori', 'Cobalt no chikara' and 'Ruchiking'. Breed. Sci. 2019, 69, 514-520. [CrossRef]

89. Gao, J.; Wang, T.T.; Liu, M.X.; Liu, J.; Zhang, Z.W. Transcriptome analysis of filling stage seeds among three buckwheat species with emphasis on rutin accumulation. PLOS ONE 2017, 12, e0189672. [CrossRef]

90. Wang, L.J.; Sheng, M.Y.; Wen, P.C.; Du, J.Y. Morphological, physiological, cytological and phytochemical studies in diploid and colchicine-induced tetraploid plants of Fagopyrum tataricum (L.) Gaertn. Bot. Stud. 2017, 58, 1-12. [CrossRef]

91. Li, C.H.; Xie, Z.M.; Wang, Y.Q.; Lu, W.J.; Yin, G.F.; Sun, D.W.; Ren, C.Z.; Wang, L.H. Correlation and genetic analysis of seed shell thickness and yield factors in Tartary buckwheat (Fagopyrum tataricum (L.) Gaertn.). Breed. Sci. 2019, 69, 464-470. [CrossRef]

92. Srejović, V.; Nesković, M. Regeneration of plants from cotyledon fragments of buckwheat (Fagopyrum esculentum Moench). Z. Pflanzenphysiol. 1981, 104, 37-42. [CrossRef]

93. Miljuš Djukić, J.; Nesković, M.; Ninković, S.; Crkvenjakov, R. Agrobacterium-mediated transformation and plant-regeneration of buckwheat (Fagopyrum esculentum Moench). Plant Cell Tissue Organ Cult. 1992, 29, 101-108. [CrossRef]

94. Luthar, Z.; Marchetti, S. Plant regeneration from mature cotyledons in a buckwheat (Fagopyrum esculentum Moench.) germplasm collection. Fagopyrum 1994, 14, 65-69.

95. Woo, S.H.; Nair, A.; Adachi, T.; Campbell, C.G. Plant regeneration from cotyledon tissues of common buckwheat (Fagopyrum esculentum Moench). In Vitro Cell. Dev. Biol. Plant 2000, 36, 358-361. [CrossRef]

96. Yamane, Y. Induced differentiation of buckwheat plants from subcultured calluses in Vitro. Jpn. J. Genet. 1974, 49, 139-146. [CrossRef]

97. Lachmann, S.; Adachi, T. Callus regeneration from hypocotyl protoplasts of Tartary buckwheat (Fagopyrum tataricum Gartn.). Fagopyrum 1990, 10, 62-64.

98. Suvorova, G. Buckwheat tissue cultures and genetic transformation. Mol. Breed. Nutr. Asp. Buckwheat 2016, 365-375. [CrossRef] 
99. Acquaah, G. Principles of Plant Genetics and Breeding, 2nd ed.; Wiley-Blackwell: Oxford, UK, 2012; p. 758.

100. Brown, J.; Caligari, P.; Campos, H. Plant Breeding. In Introduction to Plant Breeding-Revised and Updated, 2nd ed.; Wiley-Blackwell: Oxford, UK, 2014; p. 287.

101. Niroula, R.K.; Sah, B.P. Interspecific hybrids of buckwheat (Fagpyrum spp.) regenerated through embryo rescue. Sci. World 2006, 4, 74-77.

102. Woo, S.H.; Roy, S.K.; Kwon, J.S.; Cho, S.W.; Kim, H.H. Interspecific crosses between Fagopyrum cymosum and other species through embryo culture techniques. In Buckwheat Germplasm in the World; Zhou, M., Kreft, I., Suvorova, G., Tang, Y., Woo, S.H., Eds.; Academic Press, An Imprint of Elsevier: London, UK, 2018; pp. 249-258. [CrossRef]

103. Fesenko, N.N.; Fesenko, I.N. Silencing of dominant genes in heterozygous genotypes of interspecific hybrids Fagopyrum esculentum Moench X C2026 F. homotropicum Ohnishi. Russ. J. Genet. 2016, 52, 383-390. [CrossRef]

Publisher's Note: MDPI stays neutral with regard to jurisdictional claims in published maps and institutional affiliations.

(C) 2020 by the authors. Licensee MDPI, Basel, Switzerland. This article is an open access article distributed under the terms and conditions of the Creative Commons Attribution (CC BY) license (http://creativecommons.org/licenses/by/4.0/). 